\title{
Performance of seedlings of the invasive alien tree Schinus molle L. under indigenous and alien host trees in semi-arid
} savanna

\author{
Donald M. Iponga ${ }^{1,2}$, Suzanne J. Milton ${ }^{1}$ and David M. Richardson ${ }^{2 *}$ \\ ${ }^{1}$ Centre for Invasion Biology, Department of Conservation Ecology and Entomology, Stellenbosch University, Private Bag X1, Matieland 7602, \\ South Africa and ${ }^{2}$ Centre for Invasion Biology, Department of Botany and Zoology, Stellenbosch University, Private Bag X1, Matieland 7602, \\ South Africa
}

\begin{abstract}
We assessed the importance of host trees in influencing invasion patterns of the alien tree Schinus molle L. (Anacardiaceae) in semi-arid savanna in South Africa. Recruitment of $S$. molle is dependent on trees in its invaded habitat, particularly Acacia tortilis Hayne. Another leguminous tree, the invasive alien mesquite (Prosopis sp.), has become common in the area recently, but $S$. molle rarely recruits under canopies of this species. Understanding of the association between these species is needed to predict invasion dynamics in the region. We conducted experiments to test whether: (i) seedling survival of $S$. molle is better beneath A. tortilis than beneath mesquite canopies; (ii) growth rates of $S$. molle seedlings are higher beneath $A$. tortilis than beneath mesquite. Results showed that growth and survival of $S$. molle did not differ significantly beneath the native $A$. tortilis and the alien Prosopis species. This suggests that microsites provided by canopies of mesquite are as good for S. molle establishment as those provided by the native acacia. Other factors, such as the failure of propagules to arrive beneath mesquite trees, must be sought to explain the lack of recruitment beneath mesquite.
\end{abstract}

Key words: biological invasions, facilitation, invasion dynamics, invasive species, microsites, transplanting

\section{Résumé}

Nous avons évalué l'importance des arbres hôtes dans les facteurs qui influencent les schémas d'envahissement de l'arbre exotique Scinus molle L. (Anacardiaceae) dans une savane semi aride d'Afrique du Sud. Le recrutement de

*Correspondence: E-mail: rich@sun.ac.za
S. molle dépend des arbres de l'habitat qu'il envahit, et particulièrement de l'Acacia tortilis Hayne. Un autre arbre de la famille des légumineuses, l'envahissant «mesquite " (Prosopis sp.), est devenu commun dernièrement dans la région, mais $S$. molle recrute rarement sous la canopée de cette espèce. Il est nécessaire de bien comprendre l'association entre ces espèces pour prévoir la dynamique des envahissements dans la région. Nous avons réalisé des expériences pour tester si : i) la survie des jeunes plants de S. molle est meilleure sous une canopée d'Acacia tortilis que de «mesquite »; ii) le taux de croissance des jeunes plants de $S$. molle est supérieur sous les A. tortilis que sous les " mesquite ». Les résultats montrent que la croissance et la survie de $S$. molle ne sont pas significativement différentes sous les espèces natives Acacia tortilis natifs et sous les espèces exotiques de Prosopis. Ceci suggère que les microsites constitués par les canopées de "mesquite » sont aussi bons pour l'établissement de $S$. molle que ceux qu'offrent les acacias natifs. D'autres facteurs, tels que le fait que les propagules ne parviennent pas à arriver jusque sous les "mesquite ", pourraient être invoqués pour expliquer le manque de recrutement sous ces arbres.

\section{Introduction}

The invasion of woody plants into grasslands or savannas is often initially slow, especially for fleshy-fruited alien plants (Scholes \& Archer, 1997; Briggs, Hoch \& Johnson, 2002). In the initial phase, isolated trees represent focal points for bird activity, and therefore for recruitment of bird-dispersed indigenous and alien plants (Flores-flores \& Yeaton, 2000; Dean et al., 2002; Milton et al., 2007). Once founder trees mature and propagule pressure increases, 
subsequent displacement of grassland vegetation can occur rapidly (Van Auken, 2000; Briggs et al., 2002). Abundant seed input (high propagule pressure) can play a role in accelerating invasions by woody plants, particularly for bird-dispersed species (Berlow, D’Antonio \& Reynolds, 2002). More specifically, species with bird-dispersed seeds can potentially infiltrate natural nucleation processes, thereby disrupting crucial processes in savanna ecosystems (Milton et al., 2007).

Schinus molle L. (Anacardiaceae; Peruvian pepper tree), an alien tree from South America, recently started invading natural semi-arid savannas near Kimberley in South Africa's Northern Cape province. In this area, $S$. molle usually occurs in association with, and frequently overtops, the native tree Acacia tortilis Hayne (Fabaceae: Mimosoidea) (Milton et al., 2007; Iponga, Milton \& Richardson, 2008b), but seldom occurs in association with another widespread and common tree in the area, the invasive alien mesquite (Prosopis sp. - a hybrid of several Prosopis species; also Fabaceae: Mimosoidea). This pattern could be due to: (i) the failure of seeds of $S$. molle to arrive below mesquite canopies; (ii) the inability of $S$. molle seeds to germinate below mesquite canopies; or (iii) the failure of $S$. molle seedlings to survive beneath mesquite trees. This study addresses potential reasons for third point mentioned above, and compares the performance of $S$. molle seedlings planted under the canopies of the two trees species to determine whether either species is facilitating or limiting recruitment of $S$. molle seedlings.

\section{Material and methods}

The experiment was conducted between March 2006 and April 2007 on 50- to 80-year-old diamond mining tailings on the De Beers Mine near the town of Kimberley (28.76091178 degrees S; 24.79271270 degrees E) in the Northern Cape province, South Africa. The climate is semiarid with the mean annual rainfall of $431 \pm 127 \mathrm{~mm}$. The mean monthly temperature range is from $35^{\circ} \mathrm{C}$ to $18^{\circ} \mathrm{C}$ in January and from $20^{\circ} \mathrm{C}$ to $3^{\circ} \mathrm{C}$ in July (South Africa Weather http://www.weathersa.co.za/Climat/Climstats/ Kimberleystats.jsp). Over the past 50 years the alien tree $S$. molle has been grown as a shade tree, and planted at many picnic sites along national and provincial roads in South Africa (see Milton et al., 2007 for more details). Both A. tortilis and Prosopis sp. are deep-rooted, microphyllous leguminous trees belonging to the Mimosoideae that occur in semi-arid savanna. Umbrella Thorn Acacia (A. tortilis) is a medium to large microphyllous tree native primarily to savannahs of Africa. Prosopis is a genus of about 45 species of leguminous spiny trees and shrubs native to subtropical and tropical regions of the Americas. Several Prosopis species introduced to regions outside their native ranges for agroforestry purposes have become invasive (Richardson, Binggeli \& Schroth, 2004). In southern Africa the most invasive forms are hybrids of Prosopis glandulosa Torr., Prosopis juliflora (Sw.) DC and Prosopis velutina Wooton (Zimmerman, 1991).

To test the effect of host tree type on seedling performance, ten trees each of A. tortilis and Prosopis sp. (hereafter acacia and mesquite) with approximately the same canopy size, separated from each other by a distance of approximately $20 \mathrm{~m}$ were randomly selected on an old mine tailings of De Beers Mine in Kimberley. Seedlings of $S$. molle were grown in a greenhouse at Stellenbosch University. When seedlings reached a height $80-100 \mathrm{~mm}$ they were transplanted into the field, three seedlings beneath the canopy of each host tree at different directions (S, N and E) relative to the tree trunk. A total of 60 seedlings were transplanted in the site, 30 under canopies of each of the two tree species. The performance of each seedling was recorded monthly for fifteen months in terms of height, canopy area, stem basal diameter (measured with vernier callipers), and number of branches produced per seedling.

Canopy area was calculated using the following formula for an ellipse (Bronstein \& Semendjajew, 1991): Cover $=(\mathrm{Pi} / 4)$.canopy 1 .canopy $2(1)$, where canopy 1 and canopy 2 are two perpendicular diameters of the plant as seen from above. One-way analysis of variance (ANOVA; Statistica 6.1, StatSoft, Inc, 2003) was used to test separately the effect of host tree (acacia versus mesquite) after testing for normality and homogeneity of the data, followed by bootstrapping on the measured seedlings parameters (plant height, canopy area, change in stems basal area and number of branches) at the end of the experiment. Seedling survival at each recording stage was examined in terms of the proportion of seedlings that survived relative to the total number of planted seedlings planted per host tree. Because we used count data, a generalized nonlinear model, with a log-link function to a Poisson distribution was used to test for differences in number of seedlings that survived compare to dead seedlings between host tree type (acacia and mesquite) (Statistica 6.1, StatSoft Inc. 2003). 


\section{Results}

Schinus molle seedling performance was not significantly different when planted below canopies of acacia and mesquite trees (Table 1). The cumulative proportion of $S$. molle seedling survival was the same beneath canopies of the two species: $40 \%$ (Table 2).

\section{Discussion}

In semi-arid savannas of South Africa, microsites provided by large acacia trees increase the growth and survival of alien S. molle seedlings (Iponga et al., 2008b). Similar patterns have been reported from grasslands in other parts of the world. For example, shading has been shown to increase the growth of seedlings of both the alien tree $\mathrm{Sa}$ pium sebiferum (L) Roxb. and the native tree Celtis laevigata Spreng. in Texas (Siemann \& Rogers, 2003). Our study was designed to examine the performance of $S$. molle seedlings planted beneath A. tortilis and Prosopis sp., similar trees in the sub-family Mimosoideae, one native and one alien. Given that Milton et al. (2007) showed that fleshy fruited aliens were confined to sub-canopy sites and that there were more beneath native acacias than beneath alien mesquite trees in the savanna. Our expectation was that $S$. molle seedling performance and survival would be much reduced beneath mesquite canopies relative to that beneath acacia canopies. Possible causes of differences in the sub-canopy environmental between acacia and mesquite might include shade density, root competition or allelopathic influences. This would explain why association between mature $S$. molle and mesquite trees was much less common than that between acacia and $S$. molle. However, results of the transplanting experiment revealed

Table 1 Mean heights $( \pm$ SE), mean canopy areas $( \pm$ SE), mean number of branches $( \pm$ SE) and mean stem basal diameter $( \pm$ SE) of surviving seedlings of Schinus molle after fourteen months beneath Acacia tortilis and Prosopis sp.

\begin{tabular}{lccc}
\hline Variables/treatments & Prosopis sp. & Acacia tortilis & $P$ values \\
\hline $\begin{array}{l}\text { Height }(\mathrm{cm}) \\
\text { Canopy areas }\left(\mathrm{cm}^{2}\right)\end{array}$ & $215.71 \pm 47.54 \pm 3.46$ & $45.79 \pm 3.60$ & 0.24 \\
$\begin{array}{l}\text { Number of } \\
\text { branches }\end{array}$ & $2.07 \pm 0.65$ & $2.91 \pm 0.68$ & 0.38 \\
$\begin{array}{l}\text { Stem basal } \\
\text { diameter }\left(\mathrm{mm}^{2}\right)\end{array}$ & $0.32 \pm 0.02$ & $0.35 \pm 0.02$ & 0.29 \\
\hline
\end{tabular}

$P$ values were obtained through one-way ANOVA. no such differences in seedling performance and survival beneath the two host trees.

Since microsites provided by the two dominant tree species in the region afford similar opportunities for seedling survival and growth, we need to seek other explanations for the failure of mesquite trees to act like acacia in facilitating $S$. molle invasion. The most obvious explanations are: a lack of propagules arriving below mesquite canopies; or high predation of seeds below mesquite canopies. Dean et al. (2002) suggested that the canopy architecture of invasive mesquite in the Northern Cape discourages utilization of these trees by local birds. Importantly, most branches of mesquite trees are angled too steeply to provide good perches for birds. Bird species richness and diversity in woodlands dominated by native Acacia differed substantially from woodlands invaded by alien mesquites, with a general trend of fewer species and fewer individuals in mesquite-invaded woodland (Dean et al., 2002). Research is required to determine the implications for seed dispersal of $S$. molle, and thus its invasion dynamics, in mesquite-invaded ecosystems. Such work is currently underway.

The seed predation hypothesis was not tested in this study. However, the seeds of the indigenous Acacia spp. are heavily parasitized by indigenous bruchid beetles (Coleoptera) and seeds of Prosopis spp. are now parasitized by two endophagous Coleoptera introduced for biological control (Zimmermann, 1991). On the other hand, damage to $S$. molle seeds is caused mainly by a southern African wasp species limited to Anacardiaceae (Iponga et al., 2008a). A study of the dispersal of $S$. molle seed in semi-arid savannas in South Africa showed that birds can move seeds distances of up to $320 \mathrm{~m}$ from female trees, but that most seeds were deposited within $50 \mathrm{~m}$ of putative source trees (Iponga, Milton \& Richardson, 2009). It is unlikely that the wasp would parasitize seeds dispersed by birds beneath mesquite more frequently than

Table 2 Log-link function to a Poisson distribution of the mean ( \pm SE) number of seedlings of Schinus molle that survived for fourteen months for different host tree types (Acacia tortilis and Prosopis sp.)

\begin{tabular}{|c|c|c|c|c|c|}
\hline Treatments & Dead & $\begin{array}{l}\% \\
\text { dead }\end{array}$ & Alive & $\begin{array}{l}\% \\
\text { alive }\end{array}$ & $\begin{array}{l}\text { Total } \\
\mathrm{n}\end{array}$ \\
\hline Prosopis sp. & 17 & 56.66 & 13 & 43.33 & 30 \\
\hline Acacia tortilis & 18 & 60.00 & 12 & 40.00 & 30 \\
\hline
\end{tabular}


seeds dispersed to acacia sub-canopy sites, particularly as native species of Anacardiaceae are more abundant beneath acacia than mesquite in this woodland (Milton et al., 2007).

We have rejected the seedling performance hypothesis for explaining lack of $S$. molle association with mesquite. Of the alternative explanations, poor dispersal of seeds to mesquite canopies by birds is probably the most convincing. Although Milton et al. (2007) showed that S. molle can germinate below mesquite tree in this savanna, the seed germination and seed predation hypotheses have not yet been tested.

In conclusion, we believe that invasion of southern African arid savanna by mesquite will have a negative to neutral effect on the rate of invasion of this ecosystem by $S$. molle. However, where mesquite trees are invading grasslands where few other perches are available to birds, the alien host might provide microsite conditions that would advance of the invasion of $S$. molle or other fleshy fruited alien tree species.

\section{Acknowledgements}

We acknowledge the DST-NRF Centre of Excellence for Invasion Biology for financial support. Donald Iponga acknowledges supported from l' Institut de Recherche en Ecologie Tropicale (IRET), Centre National de la Recherche Scientifique et Technologique (CENAREST), Gabon.

\section{References}

Berlow, E.L., D'Antonio, C.M. \& Reynolds, S.A. (2002) Shrub expansion in montane meadows: the interaction of local-scale disturbance and site aridity. Ecol. Appl. 12, 1103-1118.

Briggs, J.M., Hoch, G.A. \& Johnson, L.C. (2002) Assessing the rate, mechanisms and consequences of the conversion of tallgrass prairie to Juniperus virginiana forest. Ecosystems 5, 578-586.

Bronstein, I.N. \& SEMENDJAJEW, K.A. (1991) Taschenbuch der Mathematik, 25th edn. B.G. Teubner Verlagsgesellschaft, Stuttgart
Dean, W.R.J., Anderson, M.D., Milton, S.J. \& Anderson, T.A. (2002) Avian assemblages in Acacia and Prosopis drainage line woodland in the Kalahari, South Africa. J. Arid Environ. 51, 120 .

FLoREs-flores, J.L \& YeATON, R.I. (2000) La importancia de la competencia en la organización de las comunidades vegetales en el altiplono Mexicano. Interciencia 25, 365-371.

Iponga, D.M., CudA, J.P., Milton, S.J. \& Richardson, D.M. (2008a) Insect seed predation in Schinus molle (Peruvian pepper tree) differs with rainfall seasonality in South Africa: Implications for invasiveness. Afr. Entomol. 16, 127-131.

Iponga, D.M., Mitton, S.J. \& Richardson, D.M. (2008b) Superiority for light: a crucial attribute defining the impact of the invasive alien tree Schinus molle (Peruvian pepper tree) in South Africa. J. Arid Environ. 72, 612-623.

Iponga, D.M., Mitton, S.J. \& Richardson, D.M. (2009) Reproductive potential and seedling establishment of the invasive alien tree Schinus molle (Anacardiaceae) in South Africa. Austral Ecol. 34. Doi:10.1111/j.1442-9993.2009.01975.x.

Milton, S.J., Wilson, J.R.U., Richardson, D.M., Seymour, C.L., Dean, W.R.J., IPONGA, D.M. \& PRocheş, Ş. (2007) Invasive alien plants infiltrate bird-mediated shrub nucleation processes in arid savanna. J. Ecol. 95, 648-661.

Richardson, D.M., Binggeli, P. \& Schroth, G. (2004) Invasive agroforestry trees: problems and solutions. In: Agroforestry and Biodiversity Conservation in Tropical Landscapes (Eds. G. ScHRoth, G.A.B. De Fonseca, C.A. Harvey, C. Gascon, H. Vasconcelos and A.-M. N. IZAC). Island Press, Washington, DC, pp. 371-396.

Scholes, R.J. \& ARCHER, S.R. (1997) Tree-grass interactions in savannas. Ann. Rev. Ecol. Syst. 28, 517-544.

SiEmann, E. \& Rogers, W.E. (2003) Changes in light and nitrogen availability under pioneer trees may indirectly facilitate tree invasions of grasslands. J. Ecol. 91, 923-931.

STATSoft, Inc. (2003) STATISTICA (data analysis software system), version 6. http://www.statsoft.com.

Van Auken, O.W. (2000) Shrub invasions of North American semiarid grasslands. Ann. Rev. Ecol. Evol. Syst. 31, 197-215.

Zimmermann, H.G. (1991) Biological control of mesquite, Prosopis spp. (Fabaceae), in South Africa. Agr. Ecosyst. Environ. 37, 175-186.

(Manuscript accepted 23 November 2008)

doi: 10.1111/j.1365-2028.2009.01094.x 